\title{
Effect of Morphine Analogues on Chemotaxis in Escherichia coli
}

\author{
By SARA PERSKY-BROSH, JEAN R. YOUNG, \\ MARY J. C. HOLLAND AND ERIC J. SIMON \\ Departments of Microbiology and Medicine, New York University Medical Center, \\ New York, New York 10016, U.S.A.
}

(Received 9 January 1978; revised 1 March 1978)

Pretreatment of Escherichia coli w3110 with levorphanol, a morphine analogue, reduced chemotaxis to serine, aspartic acid and galactose. This decreased chemotaxis was not due to decreased viability or motility. Pretreatment with $1 \cdot 1 \mathrm{~mm}$-levorphanol for $1 \mathrm{~h}$, followed by washing to remove the drug prior to determination of chemotaxis, inhibited chemotaxis to each of the attractants by at least $80 \%$. Pretreatment with dextrorphan, the enantiomorph of levorphanol, or levallorphan, the $N$-allyl analogue of levorphanol, resulted in a similar inhibition of chemotaxis. Reversal of the inhibition produced by pretreatment with levorphanol required a period of growth of at least one generation time.

\section{INTRODUCTION}

We have previously reported that levorphanol, a synthetic analogue of morphine, produces a number of metabolic effects on Escherichia coli including growth inhibition (Simon, 1964), decreased RNA synthesis (Simon \& Van Praag, 1964a,b), changes in membrane phospholipid composition (Wurster et al., 1971), inhibition of putrescine uptake (Simon, Schapira \& Wurster, 1970 b) and stimulation of putrescine efflux (Simon et al., 1970b).

Levorphanol also inhibits the transport of amino acids by intact cells (Simon et al., $1970 b$ ) and by isolated cytoplasmic vesicles (Holland \& Simon, 1975) of E. coli. These and other studies (Greene \& Magasanik, 1967; Gale, 1970a, $b$; Devinck et al., 1971; Knape, Boquet \& Röschethaler, 1972) have suggested that levorphanol and related drugs alter the properties of bacterial cell membranes.

Motile strains of $E$. coli are attracted to or repelled by a variety of chemicals (Weibull, 1960; Adler, 1966, 1969, 1973; Mesibov \& Adler, 1972; Adler, Hazelbauer \& Dahl, 1973). This phenomenon is called chemotaxis. Tsang, Macnab \& Koshland (1973) have shown that bacterial attractant and repellent concentration gradients affect bacterial motion by decreasing or increasing tumbling. The bacteria detect the attractants by means of 'chemoreceptors'. A number of investigators (Adler, 1969; Koshland, 1974, 1977) have suggested that the study of chemotaxis, a primitive stimulus-response system, in bacteria may have relevance for the neurobiology of higher organisms. Chemotaxis of Pseudomonas fluorescens toward nutrient broth was enhanced by DL-amphetamine and epinephrine and inhibited by acetylcholine and the cannabinoid tetrahydrocannabinol (Chet, Henis \& Mitchell, 1973). This paper describes the effect of levorphanol, a potent analgesic in animals, on chemotaxis by $E$. coli. Although the findings reported here should be of considerable interest to microbiologists and biochemists, they are of doubtful pharmacological significance since dextrorphan (the enantiomorph of levorphanol devoid of analgesic activity in animals) and levallorphan (an opiate antagonist) produced similar effects. 


\section{METHODS}

Bacteria. Escherichia coli w3110 was obtained from J. Adler (University of Wisconsin, U.S.A.).

Media. Bacteria were grown in minimal medium as described by Adler (1966) with glycerol or galactose $\left(5 \mathrm{~g} \mathrm{l}^{-1}\right)$ as the carbon source. For experiments on chemotaxis to galactose, bacteria were grown in medium containing galactose. For all other experiments, glycerol served as the carbon source.

Chemicals. Levorphanol, dextrorphan and levallorphan were the generous gift of Hoffman-LaRoche, Nutley, New Jersey, U.S.A. Serine and aspartic acid were purchased from Mann Research Laboratories, New York, U.S.A. Galactose was obtained from Calbiochem. All other materials were of reagent grade and were obtained from commercial sources.

Levorphanol treatment. The $\mathrm{pH}$ of an exponential phase culture was adjusted to $7 \cdot 7$ to $7 \cdot 9$ and the culture was divided into two portions. Levorphanol at a final concentration of $1 \cdot 1$ to $1.3 \mathrm{~mm}$ was added to one portion and incubation at $37^{\circ} \mathrm{C}$ was continued for 30 or $60 \mathrm{~min}$. Cells were then either filtered or centrifuged and washed twice in chemotaxis medium to remove the drug. The conditions for each experiment are given in the figure and table legends.

Chemotaxis assay. Chemotaxis of control and drug-pretreated $E$. coli to each of the attractants was measured by the capillary assay described by Adler (1973). Micropipettes ( $2 \mu \mathrm{l}$; Drummond Scientific Co.) served as capillaries. Unless otherwise indicated, suspensions of bacteria were incubated in the presence of capillaries for $60 \mathrm{~min}$ at $37^{\circ} \mathrm{C}$. Capillaries were then washed to remove bacteria from their exterior surfaces. The number of bacteria inside each capillary was determined by plating dilutions of the contents and counting the colonies after $1 \mathrm{~d}$.

Observation of bacteria by phase-contrast microscopy. Suspensions of control and drug-pretreated bacteria were examined for motility using a phase contrast microscope.

\section{RESULTS}

\section{Inhibition of chemotaxis by pretreatment with levorphanol and related drugs}

Chemotaxis of E. coli $\mathrm{w} 3110$ to serine, aspartic acid and galactose was greatly reduced by pretreatment of the organisms with levorphanol. The results of several experiments are summarized in Table 1. Pretreatment with $1 \cdot 1$ to $1.3 \mathrm{~mm}$-levorphanol for $1 \mathrm{~h}$ or less, followed by washing to remove the drug prior to determination of chemotaxis, resulted in at least $80 \%$ inhibition of chemotaxis. Pretreatment with two other drugs of the morphine series, dextrorphan and levallorphan, produced a similar inhibition of chemotaxis to serine (data not shown).

The concentrations of levorphanol employed in this study profoundly inhibit the growth of $E$. coli without killing (Simon, 1964). Microscopic observation of control and drug-pretreated cultures indicated that exposure to levorphanol did not result in diminished motility. Furthermore, the number of bacteria in capillaries not containing attractant was similar in control and drug-pretreated bacterial suspensions (Table 2).

The time course of chemotaxis to aspartic acid in levorphanol-treated and control cultures is shown in Fig. 1. The number of bacteria entering the capillaries containing aspartic acid increased with time and had not reached a plateau after $1 \mathrm{~h}$. In contrast, the number of bacteria in capillaries not containing attractant reached a plateau in $15 \mathrm{~min}$. Levorphanol pretreatment resulted in profound inhibition of chemotaxis in $15 \mathrm{~min}$, the earliest time point studied.

\section{Reversal of levorphanol inhibition of chemotaxis}

The inhibition of chemotaxis produced by levorphanol pretreatment required a period of growth for reversal. Standing in chemotaxis buffer at room temperature, for example, was not sufficient for reversal of inhibition. Cells had to be washed free of levorphanol, resuspended in complete minimal medium, and allowed to grow for at least one generation time $(2 \mathrm{~h})$, as shown in Table 3 . 


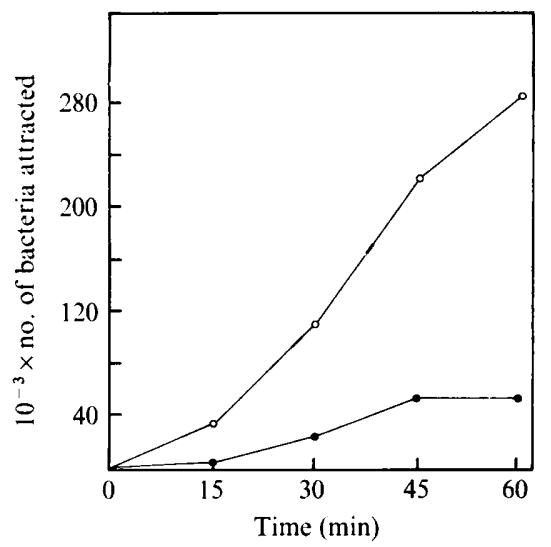

Fig. 1. Time course of chemotaxis to aspartic acid in levorphanol-treated and control cultures. Exponential phase cultures of $E$. coli $\mathrm{w} 3110$ were incubated for $30 \mathrm{~min}$ at $\mathrm{pH} 7.9$ with or without $1.3 \mathrm{~mm}$-levorphanol. Suspensions of control $(O)$ and drug-pretreated $(O)$ bacteria were incubated with capillaries containing $3 \mathrm{~mm}$ aspartic acid and with capillaries containing no attractant. At the times indicated, the number of bacteria attracted in each suspension was determined by subtracting the number of bacteria in capillaries containing no attractant from the number in capillaries containing aspartic acid.

\section{Table 1. Inhibition of chemotaxis to serine, aspartic acid and galactose by levorphanol pretreatment of $E$. coli $\mathrm{w} 3110$}

The values given are the average number of bacteria attracted for at least three experiments for each attractant. For each experiment, the number of bacteria attracted was calculated by subtracting the number of bacteria in the capillaries containing no attractant from the number in capillaries containing attractant. The conditions of levorphanol pretreatment varied slightly: for the serine chemotaxis experiments, cells were preincubated with $1.1 \mathrm{~mm}$-levorphanol at $\mathrm{pH} 7.7$ for $60 \mathrm{~min}$; for the aspartic acid experiments, the pretreatment was with $1.3 \mathrm{~mm}$ at $\mathrm{pH} 7.9$ for $30 \mathrm{~min}$; for galactose, pretreatment was with $1 \cdot 1 \mathrm{~mm}$ at $\mathrm{pH} 7 \cdot 7$ for $30 \mathrm{~min}$.

Mean no. of bacteria attracted

Attractant (concn)
Serine $(1 \mathrm{~mm})$
Aspartic acid $(3 \mathrm{~mm})$
Galactose $(0 \cdot 1 \mathrm{~mm})$

$\begin{array}{cc}\text { Control } & \text { Pretreated } \\ 340000 & 64000 \\ 215673 & 21153 \\ 44887 & 6110\end{array}$

Inhibition
$(\%)$
80
90
86

Table 2. Comparison of levorphanol-pretreated and control suspensions of E. coli for motility in the absence of an attractant

Data were obtained in six separate experiments. For each individual experiment, the number of bacteria attracted was determined for both control and drug-pretreated cultures by averaging the number of bacteria in three capillaries for each culture.

\begin{tabular}{lcc} 
& \multicolumn{2}{c}{$\begin{array}{c}\text { No. of bacteria in capillaries } \\
\text { not containing attractant }\end{array}$} \\
& Control & Pretreated \\
Mean & 2895 & 2604 \\
S.D. & 2449 & 1892 \\
S.E. & 1000 & 733
\end{tabular}




\section{Table 3. Reversal of levorphanol inhibition of chemotaxis to aspartic acid following growth in complete medium in the absence of levorphanol}

Exponential phase cultures were incubated for $30 \mathrm{~min}$ at $\mathrm{pH} 7.9$ with or without $1.3 \mathrm{~mm}-\mathrm{levor}$ phanol. Control and drug-pretreated portions were centrifuged and washed twice in chemotaxis medium. Cells were resuspended in complete growth medium for various periods of incubation at $37^{\circ} \mathrm{C}$ and then assayed for chemotaxis to aspartic acid as described in Methods.

$\begin{array}{cc}\begin{array}{c}\text { Incubation time in } \\ \text { levorphanol-free medium }\end{array} & \begin{array}{c}\text { Chemotaxis to } \\ \text { (h) } \\ \text { aspartic acid }\end{array} \\ 0 & \text { of control) } \\ 1.0 & 9 \\ 2 \cdot 0 & 28 \\ 3 \cdot 3 & 79 \\ \end{array}$

\section{DISCUSSION}

Motile bacteria are attracted by some compounds and repelled by others. Positive chemotaxis, i.e. movement toward attractants, by $E$. coli is inhibited by levorphanol pretreatment. The effect of levorphanol pretreatment on negative chemotaxis, i.e. movement away from repellents, was not investigated. Levorphanol inhibits positive chemotaxis by $E$. coli without interfering with motility. To our knowledge, it is the first such agent found for this bacterial species, although acetylcholine, tetrahydrocannabinol and ethanol have been reported to act on chemotaxis in Pseudomonas sp. (Chet, Fogel \& Mitchell, 1971; Chet et al., 1973) and it is possible that these agents may produce similar effects in $E$. coli.

In contrast to the effects of levorphanol on RNA synthesis (Simon \& Van Praag, 1964a, b), RNA phage replication (Simon, Garwes \& Rand, 1970 a) and putrescine and amino acid transport (Simon et al., 1970b; Holland \& Simon, 1975), which required the presence of the drug and were readily reversed upon its removal, chemotaxis was profoundly inhibited when cells were pretreated and the drug removed prior to testing. Reversal of levorphanol inhibition required at least one generation time in complete growth medium before normal chemotaxis was restored, suggesting the necessity to regenerate a component lost during exposure to the drug. This possiblity is supported by the absence of reversal when cells were resuspended in chemotaxis buffer. Identification of the component lost during drug exposure is of considerable interest for the study of chemoreception in E. coli.

The bacterial chemotaxis system is a rudimentary sensory receptor system and may serve as a model for neural functioning in higher organisms. Bacterial chemoreceptors, in common with neuroreceptors of higher species, demonstrate specificity of response to stimuli and respond to ratios of concentrations rather than to differences (Koshland, 1977). The neuroreceptors of higher species reside in the membrane of the cell (Simon, 1976). The chemoreceptors responsible for the recognition of gradients of attractants and repellents by $E$. coli are also thought to be associated with the cell surface (Adler, 1969). For example, part of the galactose chemoreceptor is the galactose-binding protein (Anraku, 1968; Hazelbauer \& Adler, 1971), which presumably resides in the periplasmic space, i.e. the space between the cell membrane and the cell wall (Heppel, 1971). Bacterial chemotaxis can be used to elucidate mechanisms of drug action on chemoreception.

Effects of morphine analogues in $E$. coli generally require relatively high drug concentrations, exhibit little stereospecificity, and are not antagonized by compounds known to be effective antagonists of analgesic and narcotic effects of morphine and its analogues in animals and man. In the present study, for example, levorphanol, dextrorphan (the enantiomorph of levorphanol devoid of analgesic activity in animals) and levallorphan (an opiate antagonist) were equally effective inhibitors of chemotaxis. This is not surprising since $E$. coli does not contain opiate receptors (Simon, 1976) which confer structural and steric 
specificity on these drugs in animals and man. Once the drug is attached to a receptor, however, its biochemical action may resemble that seen in the $E$. coli model system.

The findings reported here provide further evidence that levorphanol may alter the properties of cell membranes. Levorphanol pretreatment of $E$. coli produces a profound inhibition of chemotaxis toward each of three attractants without inhibiting motility, suggesting that recognition of the attractant by the chemoreceptor may be impaired by levorphanol pretreatment. It is also possible that levorphanol-pretreated $E$. coli recognize the attractant, but are unable to translate the sensed data into action. In chemotactic bacteria a change in the concentration of an attractant or repellent, once recognized by a chemoreceptor, results in a change in swimming behaviour (Koshland, 1977). In the absence of a gradient, $E$. coli swims in a straight or slightly curved 'run', lasting for a few seconds, and then tumbles for about a tenth of a second (Berg \& Brown, 1972). After each period of tumbling, the bacterium initiates another run in a new, random direction. In a gradient of attractant or repellent, the frequency of tumbling is altered (Tsang et al., 1973). If the bacterium is swimming either toward a higher concentration of an attractant or away from a higher concentration of repellent, the frequency of tumbling is inhibited and, as a consequence, the length of a run in the direction of a more favorable environment is increased. Conversely, if the bacterium is swimming either away from a higher concentration of an attractant or toward a higher concentration of a repellent, the frequency of tumbling is increased and the run in that direction is shortened. Levorphanol-pretreated $E$. coli resemble 'che' mutants which are motile but do not respond to changes in attractant or repellent concentrations (Armstrong \& Adler, 1969). 'Che' mutants fail to synthesize one of six different soluble polypeptides (Silverman \& Simon, 1977). Drug pretreatment may result in the loss of one of these polypeptides.

This research was supported by grant DA-00017 from the National Institute on Drug Abuse and by Public Health Service fellowship no. 4 FO2 GM53182-03 to M.J.C.H. from the National Institute of General Medical Sciences. Some of this work was included in the dissertation of J.R.Y. submitted to the Department of Microbiology of the Graduate School of Arts and Sciences in partial fulfilment of the requirements for the degree of Master of Science at New York University.

\section{REFERENCES}

Adler, J. (1966). Chemotaxis in bacteria. Science 153, 708-716.

ADLER, J. (1969). Chemoreceptors in bacteria. Science 166, 1588-1597.

ADLER, J. (1973). A method for measuring chemotaxis. Journal of General Microbiology 74, 77-91.

Adler, J., Hazelbauer, G. L. \& Dahl, M. M. (1973). Chemotaxis towards sugars in Escherichia coli. Journal of Bacteriology 115, 824-847.

ANRAKU, Y. (1968). Transport of sugars and amino acids in bacteria. I. Purification and specificity of the galactose- and leucine-binding proteins. Journal of Biological Chemistry 243, 3116-3122.

Armstrong, J. B. \& Adler, J. (1969). Complementation of nonchemotactic mutants of Escherichia coli. Genetics 61, 61-66.

BerG, H. C. \& Brown, D. A. (1972). Chemotaxis in Escherichia coli analysed by three-dimensional tracking. Nature, London 239, 500-504.

Chet, I., Fogel, S. \& Mitchell, R. (1971). Chemical detection of microbial prey by bacterial predators. Journal of Bacteriology 106, 863-867.
Chet, I., Henis, Y. \& Mitchell, R. (1973). Effect of biogenic amines and cannabinoids on bacterial chemotaxis. Journal of Bacteriology 115, 12121218.

Devinck, M. A., Boquet, P. L., Fromageot, P. \& Simon, E. J. (1971). On the mode of action of levallorphan on Escherichia coli: effects on cellular magnesium. Molecular Pharmacology 7, 605-610.

Gale, E. F. (1970a). Effects of diacetylmorphine and related morphinans on some biochemical activities of Staphylococcus aureus. Molecular Pharmacology 6, 128-133.

GALE, E. F. $(1970 b)$. Effects of morphine derivatives on lipid metabolism in Staphylococcus aureus. Molecular Pharmacology 6, 134-145.

GrEenE, R. \& MAGASANIK, B. (1967). The mode of action of levallorphan as an inhibitor of cell growth. Molecular Pharmacology 3, 453-472.

HAzelbauer, G. L. \& Adler, J. (1971). The role of the galactose-binding protein in chemotaxis of Escherichia coli toward galactose. Nature New Biology 230, 101-104. 
HePpel, L. A. (1971). The concept of periplasmic enzymes. In Structure and Function of Biological Membranes, pp. 223-247. Edited by L. I. Rothfield. New York: Academic Press.

Holland, M. J. C. \& Simon, E. J. (1975). Inhibition by levorphanol and related drugs of amino acid transport by isolated membrane vesicles from Escherichia coli. Antimicrobial Agents and Chemotherapy 7, 530-537.

KNAPe, J., Boquet, P. L. \& Röschethaler, R. (1972). Inhibition of amino acid transport in Escherichia coli and its cell membranes. FEBS Letters 19, 311-314.

Koshland, D. E., Jr (1974). Chemotaxis as a model for sensory systems. FEBS Letters, Suppl. 40, S3-S9.

Koshland, D. E., Jr (1977). A response regulator model in a simple sensory system. Science 196, 1055-1063.

Mesibov, R. \& Adler, J. (1972). Chemotaxis toward amino acids in Escherichia coli. Journal of Bacteriology 112, 315-326.

Silverman, M. \& Simon, M. (1977). Identification of polypeptides necessary for chemotaxis in Escherichia coli. Journal of Bacteriology 130, 1317-1325.

SimoN, E. J. (1964). Inhibition of bacterial growth by drugs of the morphine series. Science 144, 543-544.

Simon, E. J. (1976). The opiate receptors. Neurochemical Research 1, 3-28.
Simon, E. J. \& Van PraAG, D. (1964a). Inhibition of RNA synthesis in Escherichia coli by levorphanol. Proceedings of the National Academy of Sciences of the United States of America 51, 877-883.

Simon, E. J. \& Van PraAg, D. (1964b). Selective inhibition of synthesis of ribosomal RNA in Escherichia coli by levorphanol. Proceedings of the National Academy of Sciences of the United States of America 51, 1151-1158.

Simon, E. J., GARwes, D. J. \& RAND, J. (1970a). Reversible inhibition of RNA phage replication and macromolecular synthesis by levorphanol. Biochemical and Biophysical Research Communications 40, 1134-1141.

Simon, E. J., Schapira, L. \& Wurster, N. (1970 $b$ ). Effect of levorphanol on putrescine transport in Escherichia coli. Molecular Pharmacology 6, 577-587.

Tsang, N., Macnab, R. \& Koshland, D. E., Jr (1973). Common mechanism for repellents and attractants in bacterial chemotaxis. Science 181, 60-63.

WeIBULl, C. (1960). Movement. In The Bacteria, vol. 1, pp. 188-193. Edited by I. C. Gunsalus and R. Y. Stanier. New York: Academic Press.

Wurster, N., Elsbach, P., Rand, J. \& Simon, E. J. (1971). Effects of levorphanol on phospholipid metabolism and composition in Escherichia coli. Biochimica et biophysica acta 248, 282-292. 